\title{
Perception and Lexicon Labeling Ability on a Child with Language Delay Diagnosed As Autistic Spectrum Disorder: A Psycholinguistic Study
}

\author{
Rohmani Nur Indah \\ Faculty of Humanities and Culture \\ Maulana Malik Ibrahim State Islamic University (UIN) Malang. \\ JI. Gajayana No. 50 Malang, East Java, Indonesia \\ rohmani_indah@yahoo.com
}

\begin{abstract}
This research focuses on the semantics acquisition of a child with language delay diagnosed as autistic spectrum disorder (ASD). The research problem is on how the child acquired the ability to comprehend meaning. It aims at answering the questions on how the child identified lexical meanings and how he labeled targeted lexicons of his first language. The approach employed in this research is descriptive qualitative to get adequate explanation on a specific language phenomenon, namely semantics acquisition. Its design is case study with the type neo-ethnographic. As the data collection method, it uses participant observation of longitudinal study considering that the research subject has familial relation with the researcher. The data analysis shows that the semantic acquisition of the research subject has complexity in vocabulary enrichment. The research subject often performs echolalic speech when he is asked to identify or label certain object given. The typical idiosyncratic speech is shown by the unique feature of limited syllable and prosody. In general, his ability to identify lexical meanings is far exceeding his ability to label objects. He also has sensitivity to perceive the non-verbal symbol performed by the people he knows well. The use of verbal language supported by non-verbal language facilitates his perception. He finds it difficult to comprehend the lexicons having similar sound as he assumes that one lexicon represents one object which typically belongs to concrete object. In addition, the ability of the research subject in labeling objects cannot be developed easily because of his difficulty in expressing ideas through words. To pronounce the words correctly, he shows high anxiety by lowering down his speech. In selecting the lexicon he also finds it hard to use pronoun, to label homonyms and to apply both polysemy and hyponym. Accordingly, he tends to communicate only to fulfill his needs by asking things, asking the listeners to do or not to do something, and
\end{abstract}


protesting something as shown in the contexts. Further, he is likely to label objects by the lexicons got from the immediate exposure.

\title{
Keywords: Autistic Spectrum Disorder (ASD), Language Acquisition, Psycholinguistics
}

\begin{abstract}
Abstrak
Penelitian ini berfokus pada pemerolehan bahasa semantik seorang anak dengan keterlambatan bahasa yang diduga sebagai gangguan spectrum autis (ASD). Masalah penelitian pada bagaimana anak itu mempunyai kemampuan untuk mengartikan. Hal ini bertujuan untuk menjawab pertanyaan bagaimana anak itu mengidentifikasi makna leksikal dan bagaimana dia menamai kosa kata yang dimaksud dengan bahasa pertamanya. Pendekatan yang digunakan dalam penelitian ini adalah kualitatif deskriptif untuk memperoleh penjelasan yang mendalam pada fenomena bahasa tertentu, yaitu pemerolehan bahasa semantic. Rancangannya adalah studi kasus dengan tipe neoethnographic. Seperti metode pengumpulan data, ini menggunakan pengamatan partisipasi dari penelitian longitudinal yang mempertimbangkan bahwa subyek penelitian ini memiliki hubungan family dengan peneliti. Analisis data menunjukkan bahwa pemerolehan bahasa semantic dari subyek penelitian memiliki kekayaan kompleksitas kosa kata. Subyek peneliti sering melakukan bahasa echolalic ketika dia disuruh untuk mengidentifkasi atau menamai obyek tertentu yang diberikan. Tipe bahasa idiosyncratic terlihat dari bentuk unik dari suku kata dan prosody yang terbatas. Secara umum, kemampuannya untuk mengidentifikasi makna leksikal yaitu jauh melampui kemampuannya untuk menamai obyek. Dia juga memiliki sensitivitas untuk mempersepsikan bahasa non verbal dengan baik yang dilakukan oleh orang yang dia cukup kenal. Penggunaan bahasa verbal didukung oleh bahasa non verbal membantu pemahaman dia. Dia menemukan kesulitan untuk memahami kosa kata yang memiliki bunyi sama seperti yang menurut dia bahwa satu kosa kata mewakili satu obyek yang mana biasanya milik dari obyek yang nyata. Selain itu, kemampuan subyek peneliti dalam menamai obyek tidak dapat dikembangkan dengan mudah karena kesulitannya dalam mengungkapkan gagasan melau kata-kata. Untuk mengucapkan secara benar, dia mengalami kecemasan yang tinggi dengan merendahkan suara bicaranya. Dalam memilih kosa kata dia juga menemukan kesulitan untuk menggunakan kata ganti, menamai homonym dan mengaplikasikan polisemi dan hiponim. Oleh sebab itu, dia cenderung untuk hanya berkomunikasi untuk memenuhi kebutuhannya dengan menanyakan benda-benda, menanyakan pendengar untuk melakukan atau tidak melakukan sesuatu dan memprotes sesuatu
\end{abstract}


seperti dalam suatu situasi. Selanjutnya, dia mungkin menamai obyek dengan kosa kata yang diperoleh dari tempat yang terbuka secara cepat.

Kata Kunci: Gangguan Spectrum Autis (ASD), Pemerolehan Bahasa, Psikolinguistik

\section{Introduction}

Autism is one of the up-to-date topics on the discussion of Psycholinguistics, especially in the field of language disorders. Until now the ins and outs of autism has not been socialized as a whole although the incidence or prevalence of growth disorders in children has increased mainly in the last decade.

The term autism was introduced by Leo Kanner in 1943 until it has become concern in Indonesia since last 1-2 decades. $43 \%$ of persons with autism have abnormalities in the parietal lobe of his brain that caused the child not to care about the environment. The disorder is also found in small brain (cerebellum), especially in lobes VI and VII that are responsible for sensory processes, memory, thinking, learning and concentration of attention (Handojo, 2004).

The number of Purkinye cells in small brain of a child's brain structure with autism spectrum is very small that cause disruption of serotonin and dopamine balance. The result is a disruption or confusion of impulses in the brain. In addition there is biochemical brain disorder that is lack of serotonin, a neurotransmitter that serves one of the forward information in the brain (Budhiman et al, 2002: 12)

The prevalence of autism these days increases significantly. Kaplan and Morris reported that one in six children in America suffer from problems such as autism, dyslexia aggressiveness, and Attention Deficit Hyperactivity Disoder (ADHD) (in McCandless, 2003: 6). 
Indonesia, as mentioned in the Reader's Digest November 2007, is ranked well below the U.S. in terms of environmental quality as the impact of pollution in all aspects. Meanwhile, the level of disruption due to brain injury such as autism positively correlated with the level of pollution, thus it can be concluded that the prevalence of autism in Indonesia especially in big cities is higher than the incidence of autism in America.

People with autism spectrum have language disorders or precisely delays in speaking, including inability to digest the information submitted by other people because of difficulties in capturing the meaning of sentence utterances. Children's' learning difficulties due to weak ability to focus, shown by the slow process of learning support this condition. Language acquisition both in phonological, morphological, syntax and semantics are often constrained child's tendency to echolalia or the repetition of the word. Children need appropriate learning strategies to suppress the tendency of echolalia.

Learning with speech therapy is not enough to guarantee the permanence of language skills since teaching children without enrichment and periodic repetition of vocabulary could cause loss of acquired vocabulary. That's why this study focuses on aspects of vocabulary as part of the acquisition at the level of lexical semantics. Thus, it will obtain a description of the pattern of acquisition of syntactic of persons with autism who have language disorders such as delays in talking.

Based on the above research background, the general problem is: How is meaning understanding in the process of the semantic acquisition for autism spectrum children with speech delay? The problems in particular are: (1) how is the ability of the child with autism spectrum in identifying lexical meaning of his/her mother tongue? And (2) how does s/he label the targeted lexicon? 


\section{Language disorders}

Broadly speaking, language disorders include the study of language disability caused by imperfections of the organ of hearing or speech, limited cognitive abilities and psychogenic disorders, and difficulty in processing linguistic information.

In speaking, there is the process of removing thoughts and feelings (of brain) orally, in the form of words or sentences. The role of the brain is to receive and understand the input language through the ears. The good function of the brain and organ of speech will make it easier to talk properly. However, those who have abnormalities of brain function and speech would have difficulty in speaking, both receptive and productive. This is known as language disorders. The fundamental reason to study language disorders is to consider the types of teaching techniques that can help children with language disorders and theoretically to determine the capacity of the normal development of language acquisition. Moreover, any specific deviation will lead us in understanding the direction of the relationship between systems of different languages. For example, language in children with mental retardation will prove about the role of intelligence in language development.

It is important to note that language disorders affect the delay in language acquisition. For example, five-year-old son has a language competence equivalent to two-year-old or deviation from the standard acquisition - children acquire language in a different order from most children, or the child has a very different capacity from their own native language. When it is viewed from the origin, language disorders can be categorized into developing language disorders (interference due to inborn abnormalities) and acquired language disorders (interference from surgery, stroke, accident or aging). 


\section{Autism spectrum and its communication capabilities}

Autism spectrum disorders in the diagnostic criteria based on DSMIV-R are: first, qualitative disorders in reciprocal social interaction, including non-verbal behavior such as eye contact, facial expressions, and positions body; failure to develop peer relationships; lack of spontaneity in sharing enjoyment, interests or achievements with other people; and less able to engage social or emotional reciprocity. Second, qualitative disorders of communication - language developmental delay or inability to speak at all; difficulty to initiate or sustain conversation with others for individuals who are able to speak; language use which is characterized with stereotypes, repetitive or lack of meaning; and lack of ability to pretend in a game. Third, rigid repetitive and stereotype patterns of behavior, interests and activities preoccupies on one or more patterns of interest; inflexibility in routines or specific rituals and non-functional; stereotype and repetitive motor movement; and settled preoccupation on object parts. A child can be diagnosed as having autistic disorder when symptoms are already visible before the child reaches the age of 36 months (Ginanjar, 2007: 6).

Children with autisms have specific behaviors classified Handojo (2004: 13) in 2 types, namely excessive and deficits behavior. Excessive Behaviors include hyperactivity and tantrums manifested in screaming, kicking, biting, scratching, hitting, etc. as well as self-abuse. Deficit behaviors are manifested in speech disorder, social behavior disorder, pretending to be deaf and inappropriate emotion such as laughing or crying for no reason and daydreaming.

In addition to disruption in communication, behavior and social interaction, persons with autism spectrum also experience sensory integration

disorder of modulation, discrimination and motor. In individuals with sensory dysfunction, there is an interruption in the sensory recording and 
interpretation that cause problems in the process of learning, developmental or behavioral (Kranowitz in Gina, 2007: 7). Therefore, sensory integration therapies that involve strong stimulation on sense are needed in order the brain improve and restore its functionality. The perspective is in line with Doman (2006: xvi) that the human brain has the immeasurably ability to restore (neuroplasticity) and recover (neurogenesis) themselves.

Children with autism spectrum have different brain from normal children. Some studies show that the abnormalities comprise differences in brain structure, immaturity of brain cells in the amygdala, and the excessive substantial development of alba and gricea in the frontal lobes. This condition causes sensory integration disorder - the ability to organize and process sensory input as well as use it to respond appropriately.

The sensory dysfunctions above have a major impact on cognitive development, emotional development, and social interaction skills including language. Due to the impaired neurological and sensory integration, the developments of these aspects are also experiencing delays or problems.

To overcome the problem of sensory, from an early age, children with autism spectrum have tried to avoid the accumulation of stimuli (stimuli overload). Ginanjar (2007: 8) concludes that most of coping behaviors are grouped into diagnostic criteria for autistic disorders such as repetitive behavior and stereotype, avoiding eye contact, withdrawal from social interactions, obsessions on certain objects or activities, repeating the words and sentences (echolalia), and implementing a rigid routine. Because of the complexity of the problems experienced by SA children, the coping behaviors which are developed is often not effective even sometimes hinder the development in various aspects.

Hence, it can be concluded from the above discussion that the spectrum of autism is complex disorder which is differentiated by its 
prevalence trigger. The disorder has impacts on the trouble to learn and communicate verbally that is caused by the limited vocabulary so that children often speak in a language that cannot be understood by the people around him.

\section{Research method}

This research focuses on the semantic acquisition of a child with language delay diagnosed as autistic spectrum disorder (ASD). The research problem is on how the child acquired the ability to comprehend meaning. It aims at answering the questions on how the child identified lexical meanings and how he labeled targeted lexicons of his first language.

The approach employed in this research is descriptive qualitative to get adequate explanation on a specific language phenomenon namely semantic acquisition. Its design is case study with neo-ethnographic. As the data collection method, it uses participant observation of longitudinal study considering that the research subject has familial relation with the researcher.

This study focuses on the application of the theory of meaning on the acquisition of semantic relations in children with special needs such as autism spectrum. If a normal child can acquire language naturally with adequate environmental exposure, it is not the case with children with autism spectrum. It takes a certain technique, patterned and tiered to ensure ease of language acquisition in children, especially vocabulary. This research will contribute significantly to the development of child language as well as a key to the success of communication skills improvement.

With improved communication skills, children will be able to verbally express their desire, can understand what the other person say, may better receive a lesson delivered through an incomprehensible language, and then 
can control their behavior because the tantrums attitude due to his confusion would be much reduced. This is the significant linkage between the reduction in hyperactivity, increased ability to learn and concentrate and the development of verbal communication skills that begins with the acquisition of vocabulary. The results of this study will be the foundation in preparing the learning patterns of vocabulary that is more integrated to achieve the expected progress.

\section{Discussion and finding}

\section{Ability perception and lexicon labeling of autistic individuals}

In this section, the data are presented based on the type of lexicon that shows the imbalance between the ability of the subject in perception and labeling. In each of the target lexicon, it describes supporting parts to form communication, perception and label of the subject. There are some words that the subject could not directly label although the subject can perceive or mere imitate.

Data 1

Imperative verb meaning 'get' or 'off something'

\begin{tabular}{|l|l|l|l|}
\hline Target Lexicon & $\begin{array}{l}\text { Supporting } \\
\text { Lexicon }\end{array}$ & $\begin{array}{l}\text { Subjek } \\
\text { Perception }\end{array}$ & $\begin{array}{l}\text { Subjek } \\
\text { Label }\end{array}$ \\
\hline AMBIL (take) & $\ldots$ itu (that) & Ambil & Ambil \\
\hline TARUH (put) & $\ldots$. di situ (there) & Taruh & Taruh \\
\hline CARI (look for) & Mana, ... (where) & Cari & Cari \\
\hline $\begin{array}{l}\text { KEMBALIKAN } \\
\text { (give it back) }\end{array}$ & Ayo ... (come on) & Kembalikan & - \\
\hline $\begin{array}{l}\text { MINTA } \\
\text { (request) }\end{array}$ & ... satu (one) & Minta & Minta \\
\hline $\begin{array}{l}\text { KASIHKAN } \\
\text { (give) }\end{array}$ & Ayo ... (come on) & Kasihkan & Kasih \\
\hline BAWA (bring) & $\ldots$ sini (here) & Bawa & Bawa \\
\hline
\end{tabular}

Data 2 
Noun related to activities

\begin{tabular}{|l|l|l|l|}
\hline Target Lexicon & $\begin{array}{l}\text { Supporting } \\
\text { Lexicon }\end{array}$ & $\begin{array}{l}\text { Subjek } \\
\text { Perception }\end{array}$ & $\begin{array}{l}\text { Subjek } \\
\text { Label }\end{array}$ \\
\hline MEJA (table) & Ambil ... (take) & Meja & $\begin{array}{l}\text { Ayo makan } \\
\text { (let's eat) }\end{array}$ \\
\hline KURSI (chair) & Bawa ....(bring) & Kursi & $\begin{array}{l}\text { Duduk sini } \\
\text { (sit down } \\
\text { here) }\end{array}$ \\
\hline $\begin{array}{l}\text { ASBAK } \\
\text { (ashtray) }\end{array}$ & Angkat ... (lift) & Asbak & $\begin{array}{l}\text { Buang sini } \\
\text { (throw it } \\
\text { here) }\end{array}$ \\
\hline TOKO (store) & Ke ... (to) & Toko & Beli (buy) \\
\hline
\end{tabular}

Data 3

Nouns related to the child song lyric

\begin{tabular}{|l|l|l|l|}
\hline Target Lexicon & $\begin{array}{l}\text { Supporting } \\
\text { Lexicon }\end{array}$ & $\begin{array}{l}\text { Subjek } \\
\text { Perception }\end{array}$ & $\begin{array}{l}\text { Subjek } \\
\text { Label }\end{array}$ \\
\hline DELMAN & $\begin{array}{l}\text { Pada hari Minggu } \\
\text { kuturut ayah ke } \\
\text { kota naik .. (on } \\
\text { Sunday, I follow } \\
\text { my father to city on }\end{array}$ & $\begin{array}{l}\text { Hari } \\
\text { Minggu }\end{array}$ & \\
HUJAN (rain) & $\begin{array}{l}\text { Tik-tik-tik bunyi... } \\
\text { (Tick-tick-tick } \\
\text { sound of rain) }\end{array}$ & Hujan & Tik-tik \\
\hline
\end{tabular}

Data 4

The word that always stuck with the emergence of other words

\begin{tabular}{|l|l|l|l|}
\hline Target Lexicon & $\begin{array}{l}\text { Supporting } \\
\text { Lexicon }\end{array}$ & $\begin{array}{l}\text { Subjek } \\
\text { Perception }\end{array}$ & Subjek Label \\
\hline PINTU (door) & Ketuk ... (knock) & Pintu & $\begin{array}{l}\text { Pintu tutup (door } \\
\text { close) }\end{array}$ \\
\hline $\begin{array}{l}\text { SUDAH } \\
\text { (already) }\end{array}$ & .. ya? (yes) & Sudah & $\begin{array}{l}\text { Sudah selesai } \\
\text { (already done) }\end{array}$ \\
\hline $\begin{array}{l}\text { TERIMA KASIH } \\
\text { (thank you) }\end{array}$ & Bilang ... (say) & $\begin{array}{l}\text { Terima } \\
\text { kasih }\end{array}$ & $\begin{array}{l}\text { Terima } \\
\text { sama-sama (you } \\
\text { are welcome) }\end{array}$ \\
\hline MATA (eye) & Ini ... (this) & Mata & Matahari (sun) \\
\hline
\end{tabular}


Data 5

Nouns refer to other objects that are not relevant.

\begin{tabular}{|l|l|l|l|}
\hline Target Lexicon & $\begin{array}{l}\text { Supporting } \\
\text { Lexicon }\end{array}$ & $\begin{array}{l}\text { Subjek } \\
\text { Perception }\end{array}$ & Subjek Label \\
\hline $\begin{array}{l}\text { LAPTOP } \\
\text { (laptop) } \\
\text { KOMPUTER } \\
\text { (computer) }\end{array}$ & Main ... (play) & $\begin{array}{l}\text { Laptop } \\
\text { Komputer }\end{array}$ & Setrika (iron) \\
\hline $\begin{array}{l}\text { BAKSO (meat } \\
\text { ball) }\end{array}$ & Beli ... (buy) & Bakso & Goreng (fry) \\
\hline TOLONG (help) & Mama ... (mom) & $\begin{array}{l}\text { Tolong } \\
\text { betulkan } \\
\text { (help, fix it) }\end{array}$ & $\begin{array}{l}\text { Minggir (step } \\
\text { aside) }\end{array}$ \\
\hline
\end{tabular}

Data 6

Words refer to other relevant parts of words

\begin{tabular}{|l|l|l|l|}
\hline Target Lexicon & $\begin{array}{l}\text { Supporting } \\
\text { Lexicon }\end{array}$ & $\begin{array}{l}\text { Subjek } \\
\text { Perception }\end{array}$ & Subjek Label \\
\hline BELOK (turn) & $\ldots$ sini (here) & Belok & Lewat (pass) \\
\hline $\begin{array}{l}\text { RAMBUTAN (a } \\
\text { kind of fruit) }\end{array}$ & Beli ...(buy) & Rambutan & Rambut (hair) \\
\hline $\begin{array}{l}\text { KIPAS ANGIN } \\
\text { (fan) }\end{array}$ & $\begin{array}{l}\text { Matikan } \\
\text { (turn off) }\end{array}$ & Kipas angin & Pesawat (plane) \\
\hline
\end{tabular}

Data 7

Words containing linkage or similarity pronunciation with different meanings

\begin{tabular}{|l|l|l|l|}
\hline Target Lexicon & $\begin{array}{l}\text { Supporting } \\
\text { Lexicon }\end{array}$ & $\begin{array}{l}\text { Subjek } \\
\text { Perception }\end{array}$ & Subjek Label \\
\hline $\begin{array}{l}\text { DADA (chest) } \\
\text { (anggota badan } \\
\text { (part of body)) }\end{array}$ & Lihat ... (look) & $\begin{array}{l}\text { Da da (bye) } \\
\text { (melambaikan } \\
\text { tangan } \\
\text { (waving) }\end{array}$ & Da da \\
\hline
\end{tabular}


Data 8

Noun representing some objects that have linkage type.

\begin{tabular}{|c|c|c|c|}
\hline Target Lexicon & $\begin{array}{l}\text { Supporting } \\
\text { Lexicon }\end{array}$ & Subjek Perception & $\begin{array}{l}\text { Subjek } \\
\text { Label }\end{array}$ \\
\hline $\begin{array}{l}\text { TAHU (a kind of } \\
\text { food) }\end{array}$ & Makan ... (eat) & Tahu, tempe & Tempe \\
\hline$G A R P U$ (fork) & Ambil ... (take) & $\begin{array}{l}\text { Garpu, sendok (fork, } \\
\text { spoon) }\end{array}$ & Sendok \\
\hline $\begin{array}{l}\text { MENGGAMBAR } \\
\text { (drawing) }\end{array}$ & $\begin{array}{l}\text { Ayo } \ldots \text { (come } \\
\text { on) }\end{array}$ & $\begin{array}{l}\text { Menggambar, } \\
\text { belajar, menulis } \\
\text { (draw, learn, write) }\end{array}$ & Belajar \\
\hline PULPEN (pen) & $\begin{array}{l}\text { Pinjam } \\
\text { (borrow) }\end{array}$ & $\begin{array}{l}\text { Pulpen, pensil, } \\
\text { spidol (pen, pencil, } \\
\text { marker) }\end{array}$ & Pensil \\
\hline $\begin{array}{l}\text { KERUPUK (a } \\
\text { kind of food) }\end{array}$ & $\begin{array}{ll}\begin{array}{l}\text { Minta } \\
\text { (request) }\end{array} & \cdots \\
\end{array}$ & $\begin{array}{l}\text { Kerupuk, keripik, } \\
\text { kue }\end{array}$ & Kue (cake) \\
\hline $\begin{array}{l}\text { TEBANG } \\
\text { (felling) }\end{array}$ & ...pohon (tree) & $\begin{array}{ll}\text { Tebang, } & \text { gunting, } \\
\text { potong } & \text { (felling, } \\
\text { cutting) } & \end{array}$ & $\begin{array}{l}\text { Gunting } \\
\text { (scissors) }\end{array}$ \\
\hline$C A B E$ (chilli) & $\begin{array}{l}\text { Ada ... (there is } \\
\text {..) }\end{array}$ & $\begin{array}{l}\text { Cabe, pedas, asam } \\
\text { (chilli, hot, sour) }\end{array}$ & Pedas \\
\hline BOTOL (botle) & ... diisi (here) & $\begin{array}{lr}\text { Botol, } & \text { gelas, } \\
\text { cangkir, } & \text { teko } \\
\text { (Bottles, } & \text { glasses, } \\
\text { cups, teapots } & \end{array}$ & $\begin{array}{l}\text { Gelas } \\
\text { (glass) }\end{array}$ \\
\hline $\begin{array}{l}\text { MULAS } \\
\text { (stomachace) }\end{array}$ & $\begin{array}{ll}\text { Perut } & \ldots \\
\text { (stomach) }\end{array}$ & $\begin{array}{l}\text { Mulas, panas, perih, } \\
\text { sakit, kembung, } \\
\text { mual (stomachace, } \\
\text { heat, soreness, pain, } \\
\text { bloating, nausea) }\end{array}$ & $\begin{array}{l}\text { Panas } \\
\text { (hot) }\end{array}$ \\
\hline$\overline{G A T A L \text { (itch) }}$ & Kaki ... (foot) & $\begin{array}{l}\text { Gatal, panas, } \\
\text { kesemutan, pegal } \\
\text { (Itching, burning, } \\
\text { tingling, aching }\end{array}$ & $\begin{array}{l}\text { Panas } \\
\text { (Hot) }\end{array}$ \\
\hline $\begin{array}{l}J E R U K \\
\text { (oranges) }\end{array}$ & Buah ... (fruit) & $\begin{array}{l}\text { Jeruk, apel, pir, } \\
\text { tomat } \\
\text { apples, } \\
\text { (Oranges, }\end{array}$ & Apel (aple) \\
\hline
\end{tabular}


Data 9

Nouns which are members of a common word

\begin{tabular}{|l|l|l|l|}
\hline Target Lexicon & $\begin{array}{l}\text { Supporting } \\
\text { Lexicon }\end{array}$ & Subjek Perception & Subjek Label \\
\hline $\begin{array}{l}\text { BINATANG } \\
\text { (animal) }\end{array}$ & Gambar ... (draw) & - & Kucing (cat) \\
\hline $\begin{array}{l}\text { BUAH- } \\
\text { BUAHAN (fruit) }\end{array}$ & Ini ... (this ) & - & Apel (aple) \\
\hline
\end{tabular}

Data 10

Question words adopted from other person

\begin{tabular}{|l|l|l|l|}
\hline Target Lexicon & $\begin{array}{l}\text { Supporting } \\
\text { Lexicon }\end{array}$ & $\begin{array}{l}\text { Subjek } \\
\text { Perception }\end{array}$ & Subjek Label \\
\hline SAKIT (sick) & Jojo ... & Sakit & $\begin{array}{l}\text { Sakit ta? (are you } \\
\text { sick?) }\end{array}$ \\
\hline $\begin{array}{l}\text { SUDAH } \\
\text { (already) }\end{array}$ & Eek .... & Sudah & $\begin{array}{l}\text { Sudah belum?(are } \\
\text { you done?) }\end{array}$ \\
\hline MAKAN (eat) & Minta ... (request) & Makan & $\begin{array}{l}\text { Makan ya?(will } \\
\text { you eat?) }\end{array}$ \\
\hline MAU (want) & Jojo ... & Mau & $\begin{array}{l}\text { Mama Mau? (do } \\
\text { you want it } \\
\text { mom?) }\end{array}$ \\
\hline
\end{tabular}

The ability of the subject to communicate on the targeted ability is two-way interactions both verbally and non-verbally including the ability to understand the purpose and express the desire. Verbal communication skills require listening and speaking. In general, most individuals with autism spectrum experience obstacles in the development of speech, including what was experienced by the subject. The type and level of severity of problems in language development is very diverse, in this case the vocabulary of the subject can be quite limited.

In autistic individuals, such as the subject, echolalia or idiosyncratic often appears with unique character of limited syllables, at least prosody and 
lack of pragmatic. The data 1 to data 10 which have been described above show the phenomena. The subject apparently got difficulty in using pronoun; hence it was often reversed, as in one instance in the data 10. The subjects also did not want to understand synonymy and homonymy like the word 'Dada' and 'da-da'. This finding agrees with Hitti (2004: 2) that children with verbal autism spectrum prefer to identify and label something, although the pronunciation is not perfect or even less precise perception. Furthermore, the subject tends to communicate only to meet his needs as to ask for something, to do something or to protest. Language for social interaction such as addressing, say hello and exchange pleasantries can not be achieved. If the subject wanted to have self introduction, the subject chose gestures such as touching the other person's cheek or arm. When giving greeting, the subject immediately embraced the other person to express a sense of missed and glad to meet. Vocabulary owned by the subject does not allow him to express empathic abilities as most people.

The main cause of speaking difficulty of children with the autism spectrum is sensory processing system disorder. The subject could hear but the perception is sometimes different from what is heard as in the data 7 and 9. This condition sometimes causes the subjects had difficulties in catching the meaning of the conversation. Eye contact is also a difficult thing to do, hence the listener need to remind he subject repeatedly.

The subject was not able to express thoughts through words; as a result his emotions sometimes went up if his intention was not understood by the listener. To recite the lexicon appropriately, the subject got anxiety to speak so that the subject turned down the volume of voice although the pronunciation was correct. The important thing to note in this aspect of language is that the inability of the subject to talk (speech) does not necessarily indicate that this individual has not achieved the language as 
described by Ginanjar (2007: 16), because the subject is gradually able to improve his language skills.

In general, the subject's ability to understand language beyond their ability in speaking, as it appears in the data 8. To express wishes, opinions and feelings, the subject has been trained to string words and sentences by pointing images and labeling, this reflects his ability to understand the world and self as speech therapy (Ginanjar, 2007: 17).

Some individuals with autism spectrum get difficulties in capturing non-verbal symbols such as body language, gestures, facial expressions, and intonation. However, it is not the case with the subject of the research. The subject has the sensitivity to perceive non-verbal symbols of other person whom the subject knew well. If the symbol is shown by foreigners, the subject does not consider them. The ability to appoint objects or direct his view to the designated objects rarely arise because prepositions 'ini' (this) or 'itu' (that) are very slowly achieved. However, the use of verbal language together with non-verbal signs is emphasized as visual signs are better understood by the subject. Hence, the learning patterns should combine communication with pictures. To learn nouns and verbs, the subject understand them after they were demonstrated

Overall, in identifying lexical meaning or perception of the lexicon, the subject may achieve targeted perceptions by some of the following conditions: (1) repeated lexicon should be pronounced clearly; (2) eye contact helps complete perception through the identification of the hearer's lips; (3) gesture supports communication; (4) imitation of labeling must be done until the learner's acquisition is close to accurate pronunciation to avoid repeated mistakes; and (5) communication should be supported by context which helps understanding such as prom or samples as well as media like pictures. 


\section{Data 11}

The summary of examples of the targeted lexicons with the semantic capabilities

\begin{tabular}{|l|l|l|l|}
\hline Data & Type of lexicon Perception & Labeling Ability \\
\hline 1 & $\begin{array}{l}\text { Imperative verbs have } \\
\text { meaning 'get' or 'off } \\
\text { something' }\end{array}$ & Accurate & $\begin{array}{l}\text { Accurate except } \\
\text { 'kembalikan' } \\
\text { (give it back) }\end{array}$ \\
\hline 2 & Nouns related to activities & Accurate & Not accurate \\
\hline 3 & $\begin{array}{l}\text { Nouns related to parts of } \\
\text { children song lyrics. }\end{array}$ & Accurate & Not accurate \\
\hline 4 & $\begin{array}{l}\text { The word that always stuck } \\
\text { with the emergence of other } \\
\text { words }\end{array}$ & $\begin{array}{l}\text { Accurate } \\
\text { objects that are not relevant }\end{array}$ & almost accurate \\
\hline 5 & $\begin{array}{l}\text { Words that refer to other } \\
\text { relevant parts of words }\end{array}$ & $\begin{array}{l}\text { Accurate } \\
\text { Accurate }\end{array}$ & $\begin{array}{l}\text { Not accurate } \\
\text { except } \\
\text { 'Rambutan' } \\
\text { kind of fruit) }\end{array}$ \\
\hline 7 & $\begin{array}{l}\text { Words containing linkage or } \\
\text { similarity pronunciation } \\
\text { with different meanings }\end{array}$ & $\begin{array}{l}\text { Not } \\
\text { accurate } \\
\text { object that has linkage type }\end{array}$ & Accurate \\
\hline 8 & $\begin{array}{l}\text { Nouns which are members } \\
\text { of a common word } \\
\text { Question words adopted } \\
\text { from other person }\end{array}$ & Accurate \\
\hline 10 & Accurate & Not accurate \\
\hline 5
\end{tabular}

In the table above, the inaccuracy of perception appears to the concept of homonymy (data 7) and hyponymy (data 9). Words containing pronunciation linkage or similarity to other meanings complicate the subject to understand them because he assumes that each lexicon represents different objects. This principle is regarded as an absolute regularity so that if irregularities appear, autistic individuals will regard it as a threat. As a result, 
his emotions rise as the phenomenon does not meet his intention - a lexicon for a single object. Similarly, it also takes place in the understanding of nouns which are members of a common word. In the subject understanding, group of objects is an absurd interpretation because the subject only understands the concept of a lexicon for one object. The subject considers that one lexicon or hyponym member is communicative enough comparing to group labeling which is abstract in the subject perception.

This finding agrees with the results of the research on children vocabulary acquisition conducted by Roger Brown (in Pecei, 2006). Brown explains that the sequence of children language acquisition is from concrete to abstract. When a child is in a certain age, she/he can develop the cognitive ability to differentiate or discriminate objects.

The subject of the research has developed this capability so that it appears a few words in the observation period which is then removed from the list of data because the subject has achieved them. Furthermore, the subject is gradually expected to show the hierarchy of vocabularies acquired. Brown also finds that category of words obtained by a child is not caused by the simplicity of form or because of the frequency of using such words, but it is more because of compliance with child cognitive development. This phenomenon appears in the data 1, 2, 3, 4, 5, 6, 8, and 10 .

Overall, the ability of the subjects in labeling the targeted lexicons are still not satisfactory and highly dependent on several conditions: (1) lexicon is imitated repeatedly until at least near correct pronunciation, (2) eye contact must exist to help the subject to imitate the lip mimic of the model, (3) labeling should be supported by context that helps the subject's understanding such as prom or a sample or media like images.

In the table above, the incorrectness of the label appears on almost all data except the imperative verb of 'get' or 'off something' (data 1), words that 
the emergence are always sticking with other words (data 4) and words having linkage or pronunciation similarity to other meanings (data 7). The three types of data are easier to pronounce than the targeted lexicon on other data.

Verbs are easier to memorize than nouns as in the data 2. Similarly, it is also in the lyrics of songs in the data 3. The frequency of words spoken by other parties made the subject memorizes words which the references indirectly refer to the targeted lexicon as in the data 5, 8, 9 and 10 . The subjects also had difficulty in distinguishing questions raised by other parties as in data 10 , hence there is a label of adoption of question words.

These findings relate to the results of the research on children vocabulary acquisition conducted by David Messer (in Peccei, 2006). He examines that language learning environment and its role in children language acquisition. For the subject, there is a strong tendency that labeling is influenced by vocabularies heard frequently. The results of analysis of this study also find that language learning environment constructs has a very important role in training children vocabulary. The subject used the lexicon label that has semantic property relevance. Even some words tend to be memorized easier if jangan (don't) or tidak (no) are added to these words.

As the finding of Messer, the vocabulary of children is more important than the application of Theory of Parameters and Principles proposed by Chomsky because fewer children apply the principles of grammar and prefer to use lexicons and vocabulary enrichment. The subjects prefer objects labeling with holophrastic speaking style (one word to represent a single sentence) as in the data 1,6 , and 7 . 


\section{Conclusions and Suggestions}

This study analyzed the ability to acquire lexical semantics or meaning of individuals with autism spectrum with language delay. As a result, it obtains a description of the ability of perception and labeling lexicon of the research subject as follows:

In the semantic level of language proficiency, the subject meets obstacles in the vocabulary enrichment. Echolalia often appears when the subject was asked to perceive or identify objects. The subject labeled the objects idiosyncratically characterized with limited syllables and prosody. Vocabulary enrichment of the subjects cannot be achieved automatically but through conditioning and training because of his difficulties in communication ability.

The achievement of the subject's perception is better than the ability in labeling; the subject could hear but his perception could be different. This condition sometimes caused the subjects had difficulty in capturing the meaning of conversation that triggered his emotions. Eye contact is also a difficult thing to do, hence the listener must often remind the subjects. The subject also has the sensitivity to perceive non-verbal symbols only from person who the subject knows well. The use of verbal language with nonverbal facilitates the perception of the subject. Words having linkage or similarity pronunciation with other meanings complicate the understanding of the subject who assumes that each lexicon applies to different objects. This principle is regarded as an absolute regularity so that deviations will trigger the subject's emotion. The subject requires a lexicon for a single object with a preference to concrete words.

Labeling ability of the subject is not easy to develop because of his inability to express thoughts through words; as a result his emotions 
sometimes went up if the other parties did not successfully capture his intention in communication. To recite the lexicon appropriately, the subject had an anxiety to speak so that the subject turned down the voice even though the subject had correct pronunciation. In the lexicon diction, the subject had difficulty in using pronouns, labeling homonymy and applying polysemy as well as hyponymy. The subjects tend to communicate only to meet his needs as to ask for something, to do something or to protest. Vocabularies which could be labeled by the subject often did not express empathic abilities as most people. Inappropriateness in labeling often appears except on imperative verb of 'get' or 'off something', words that the emergence are always stuck in other words, and words that have spelling linkage or similarity with other meanings. Subjects tended to label with the words the subject remembered from the initial exposure.

Based on empirical findings, the researcher recommends to the relevant parties as follows:

For academicians, especially teachers need to know the barriers of language learners. The particular pattern of communication in persons with autism spectrum should not have to be constraints in teaching and learning. The results of this study can be used as reference of semantics patterns of autistic that can be a reference for how to communicate with them.

For those interested in Psycholinguistics studies, they are expected to continue to develop the discourse on the field of language disorders. This study presents interesting findings on the uniqueness of the semantic patterns of persons with autism spectrum which is very specific compared to language barriers in diverse typologies.

For researchers in the field of language, the phenomenon of language acquisition deviations need to be developed further. This study can serve as initial reference about the acquisition of semantics that need to be further 
associated with the acquisition of pragmatic and syntactic. In addition, it should be followed up with research on language symptoms in persons with autism spectrum such as Asperger's Syndrome, Attention Deficit Disorder, Attention Deficit Hyperactive Disorder, Pervasive Development DisorderNot Specified, Cerebral Palsy, and so forth.

\section{References}

Budhiman, M., Shattock, P, dan Ariani, E. 2002. Langkah Awal Menanggulangi Autisme dengan Memperbaiki Metabolisme Tubuh. Jakarta: Nirmala.

Carrol, D.W. 1986. Psychology of Language. Pacivic Grove-California: Brooks/Cole Publishing Company.

Chaer, A. 2003. Psikolinguistik:Kajian Teoretik. Jakarta: PT Rineka Cipta.

Clark, H \& Clark, E.V. 1977. Psychology and Language: an Introduction to Psycholinguistics. New York: Harcourt Broce Jovanovich Inc.

Doman, G. 2006. Apa yang Dapat Dilakukan pada Anak Anda yang Cedera Otak. Jakarta: GR Press.

Field, J. 2003. Psycholinguistics: a Resource Book for Students. New York: Routledge.

Fromkin, V; Blair, D \& Collins, P. 2002. An Introduction to Language. Sydney: Harcourt, Ltd

Gleason, J. \& Ratner, M. 1998. Psycholinguistics: $2^{\text {nd }}$ edition. Victoria: Wadsworth Thomson Learning.

Ginanjar, A.S. 2007. Memahami Spektrum Autistik Secara Holistik. Disertation (accessed from www.putrakembara.com, 20 Agustus 2007)

Handojo, Y. 2004. Autisma: Petunjuk Praktis \& Pedoman Materi untuk Mengajar Anak Normal, Autis dan Prilaku Lain. Jakarta: Gramedia

Hitti, M. 2004. Gender Affects Language in Autistic Children. WebMD medical news

Indah, R.N \& Rahman, A. 2008. Psikolinguistik: Konsep dan Isu Umum. Malang: UIN Press 
McCandless, J. 2003. Children with Starving Brains Anak-anak dengan Otak yang "Lapar": Panduan penanganan medis untuk penyandang gangguan spektrum autisme, ed.2. Jakarta: Grasindo

Nababan, S.U. 1992. Psikolinguistik: Suatu Pengantar. Jakarta: Gramedia.

Piccei, J.S. 2006. Child Language. London: Routledge.

Schovel, T. 2004. Psycholinguistics: Oxford Introductions to Language Study. Oxford: Oxford University Press.

Staum, M.J. 2004. Music Therapy and Language for The Autistic Child. Diakses dari www.percepp.demon.co.uk/autism.htm 